\title{
NOTES ON THE COMPLETE ELLIPTIC INTEGRAL OF THE FIRST KIND
}

\author{
Zhen-Hang Yang, Wei-Mao Qian, Wen Zhang And Yu-Ming Chu
}

Abstract. In the article, we present several monotonicity properties and bounds for the complete elliptic integral of the first kind. As applications, we find sharp bounds for the arithmeticgeometric mean.

Mathematics subject classification (2010): 33E05, 26E60.

Keywords and phrases: Gaussian hypergeometric function, complete elliptic integral, arithmetic-geometric mean.

\section{REFERENCES}

[1] M. Abramowitz, I. A. Stegun, Handbook of Mathematical Functions with Formulas, Graphs and Mathematical Tables, Dover, New York, 1965.

[2] M. Adil Khan, S. Begum, Y. Khurshid, Y.-M. Chu, Ostrowski type inequalities involving conformable fractional integrals, J. Inequal. Appl. 2018 (2018), Article 70, 14 pages.

[3] M. Adil Khan, Y.-M. Chu, A. Kashuri, R. Liko, G. Ali, Conformable fractional integrals versions of Hermite-Hadamard inequalities and their generalizations, J. Funct. Spaces 2018 (2018), Article ID 6928130, 9 pages.

[4] M. Adil Khan, Y.-M. ChU, T. U. Khan, J. Khan, Some new inequalities of Hermite-Hadamard type for s-convex functions with applications, Open Math. 15, 1 (2017), 1414-1430.

[5] M. Adil Khan, M. Hanif, Z. A. Khan, K. Ahmad, Y.-M. Chu, Association of Jensen's inequality for s-convex function with Csiszár divergence, J. Inequal. Appl. 2019, (2019), Article 162, 14 pages.

[6] M. Adil Khan, A. Iqbal, M. Suleman, Y.-M. Chu, Hermite-Hadamard type inequalities for fractional integrals via Green's function, J. Inequal. Appl. 2018, (2018), Article 161, 15 pages.

[7] M. Adil Khan, Y. Khurshid, T.-S. Du, Y.-M. CHU, Generalization of Hermite-Hadamard type inequalities via conformable fractional integrals, J. Funct. Spaces 2018, (2018), Article ID 5357463, 12 pages.

[8] M. Adil Khan, S.-H. Wu, H. Ullah, Y.-M. Chu, Discrete majorization type inequalities for convex functions on rectangles, J. Inequal. Appl. 2019, (2019), Article 16, 18 pages.

[9] M. Adil KhAN, S. ZAheER Ullan, Y.-M. CHU, The concept of coordinate strongly convex functions and related inequalities, Rev. R. Acad. Cienc. Exactas Fís. Nat. Ser. A Mat. RACSAM 113, 3 (2019), 2235-2251.

[10] H. Alzer, S.-L. QIU, Monotonicity theorems and inequalities for the complete elliptic integrals, J. Comput. Appl. Math. 172, 2 (2004), 289-312.

[11] G. D. Anderson, M. K. Vamanamurthy, M. Vuorinen, Functional inequalities for hypergeometric functions and complete elliptic integrals, SIAM J. Math. Anal. 23, 2 (1992), 512-524.

[12] G. D. Anderson, M. K. Vamanamurthy, M. Vuorinen, Conformal Invariants, Inequalities, and Quasiconformal Maps, John Wiley \& Sons, New York, 1997.

[13] Z.-W. CAI, J.-H. HUANG, L.-H. HUANG, Generalized Lyapunov-Razumikhin method for retarded differential inclusions: applications to discontinuous neural networks, Discrete Contin. Dyn. Syst. 22B, 9 (2017), 3591-3614.

[14] Z.-W. CAI, J.-H. HuAng, L.-H. HuAng, Periodic orbit analysis for the delayed Filippov system, Proc. Amer. Math. Soc. 146, 11 (2018), 4667-4682.

[15] B. C. Carlson, J. L. Gustafson, Asymptotic expansion of the first elliptic integral, SIAM J. Math. Anal. 16, 5 (1985), 1072-1092. 
[16] Y.-M. Chu, M. Adil Khan, T. Ali, S. S. Dragomir, Inequalities for $\alpha$-fractional differentiable functions, J. Inequal. Appl. 2017 (2017), Article 93, 12 pages.

[17] Y.-M. CHU, Y.-F. QIU, M.-K. WANG, Hölder mean inequalities for the complete elliptic integrals, Integral Transforms Spec. Funct. 23, 7 (2012), 521-527.

[18] Y.-M. ChU, M.-K. WANG, Optimal inequalities between harmonic, geometric, logarithmic, and arithmetic-geometric means, J. Appl. Math. 2011 (2011), Article ID 618929, 9 pages.

[19] Y.-M. CHU, M.-K. WANG, Inequalities between arithmetic-geometric, Gini, and Toader means, Abstr. Appl. Anal. 2012 (2012), Article ID 830585, 11 pages.

[20] Y.-M. ChU, M.-K. WANG, Optimal Lehmer mean bounds for the Toader mean, Results Math. 61, 3-4 (2012), 223-229.

[21] Y.-M. ChU, M.-K. WANG, Y.-P. JiAng, S.-L. QIU, Concavity of the complete elliptic integrals of the second kind with respect to Hölder means, J. Math. Anal. Appl. 395, 2 (2012), 637-642.

[22] Y.-M. ChU, M.-K. WANG, Y.-F. QIU, On Alzer and Qiu's conjecture for complete elliptic integral and inverse hyperbolic tangent function, Abstr. Appl. Anal. 2011 (2011), Article ID 697547, 7 pages.

[23] Y.-M. ChU, M.-K. WANG, S.-L. QIU, Optimal combinations bounds of root-square and arithmetic means for Toader mean, Proc. Indian Acad. Sci. Math. Sci. 122, 1 (2012), 41-51.

[24] Y.-M. ChU, M.-K. WANG, S.-L. QIU, Y.-P. JIANG, Bounds for complete elliptic integrals of the second kind with applications, Comput. Math. Appl. 63, 7 (2012), 1177-1184.

[25] Z.-F. DAI, X.-H. Chen, F.-H. Wen, A modified Perry's conjugate gradient method-based derivative-free method for solving large-scale nonlinear monotone equations, Appl. Math. Comput. 270 (2015), 378-386.

[26] L. DUAn, X.-W. FAnG, C.-X. HUANG, Global exponential convergence in a delayed almost periodic Nicholson's blowflies model with discontinuous harvesting, Math. Methods Appl. Sci. 41, 5 (2018), 1954-1965.

[27] L. DUAn, C.-X. HUAng, Existence and global attractivity of almost periodic solutions for a delayed differential neoclassical growth model, Math. Methods Appl. Sci. 40, 3 (2017), 814-822.

[28] L. Duan, L.-H. Huang, Z.-Y Guo, X.-W. FAng, Periodic attractor for reaction-diffusion highorder Hopfield neural networks with time-varying delays, Comput. Math. Appl. 73, 2 (2017), 233-245.

[29] X.-P. FAng, Y.-J. Deng, J. LI, Plasmon resonance and heat generation in nanostructures, Math. Methods Appl. Sci. 38, 18 (2015), 4663-4672.

[30] K. Gou, B. Sun, Numerical solution of the Goursat problem on a triangular domain with mixed boundary conditions, Appl. Math. Comput. 217, 21 (2011), 8765-8777.

[31] X.-H. HE, W.-M. QIAN, H.-Z. XU, Y.-M. ChU, Sharp power mean bounds for two Sándor-Yang means, Rev. R. Acad. Cienc. Exactas Fís. Nat. Ser. A Mat. RACSAM 113, 3 (2019), 2627-2638.

[32] H.-J. Hu, X.-F. Zou, Existence of an extinction wave in the Fisher equation with a shifting habitat, Proc. Amer. Math. Soc. 145, 11 (2017), 4763-4771.

[33] C.-X. Huang, J. Gao, P. Wang, Attractor and boundedness of switched stochastic CohenGrossberg neural networks, Discrete Dyn. Nat. Soc. 2016 (2016), Article ID 4958217, 19 pages.

[34] C.-X. Huang, S. Guo, L.-Z. Liu, Boundedness on Morrey space for Toeplitz type operator associated to singular integral operator with variable Calderón-Zygmund kernel, J. Math. Inequal. 8, 3 (2014), 453-464.

[35] T.-R. Huang, B.-W. Han, X.-Y. MA, Y.-M. Chu, Optimal bounds for the generalized EulerMascheroni constant, J. Inequal. Appl. 2018 (2018), Article 118, 9 pages.

[36] C.-X. HUANG, L.-Z. LIU, Boundedness of multilinear singular integral operator with a non-smooth kernel and mean oscillation, Quaest. Math. 40, 3(2017), 295-312.

[37] C.-X. Huang, C.-L. Peng, X.-H. Chen, F.-H. Wen, Dynamics analysis of a class of delayed economic model, Abstr. Appl. Anal. 2013 (2013), Article ID 962738, 12 pages.

[38] C.-X. Huang, Y.-C. QIaO, L.-H. HuAng, R. P. Agarwal, Dynamical behaviors of a food-chain model with stage structure and time delays, Adv. Difference Equ. 2018 (2018), Article 186, 26 pages.

[39] T.-R. Huang, S.-Y. TAN, X.-Y. MA, Y.-M. ChU, Monotonicity properties and bounds for the complete p-elliptic integrals, J. Inequal. Appl. 2018 (2018), Article 239, 11 pages.

[40] C.-X. HuAng, Z.-C. YAng, T.-S. YI, X.-F. Zou, On the basins of attraction for a class of delay differential equations with non-monotone bistable nonlinearities, J. Differential Equations 256, 7 (2014), 2101-2114. 
[41] C.-X. Huang, H. Zhang, L.-H. Huang, Almost periodicity analysis for a delayed Nicholson's blowflies model with nonlinear density-dependent mortality term, Commun. Pure Appl. Anal. 18, 6 (2019), 3337-3349.

[42] C.-X. Huang, H. Zhang, J.-D. CaO, H.-J. Hu, Stability and Hopf bifurcation of a delayed preypredator model with disease in the predator, Internat. J. Bifur. Chaos Appl. Sci. Engrg. 29, 7 (2019), Article ID 1950091, 23 pages.

[43] Y.-J. JiAng, J.-T. MA, Spectral collocation methods for Volterra-integro differential equations with noncompact kernels, J. Comput. Appl. Math. 244 (2013), 115-124.

[44] Y. Khurshid, M. Adil Khan, Y.-M. Chu, Conformable integral inequalities of the HermiteHadamard type in terms of GG-and GA-convexities, J. Funct. Spaces 2019 (2019), Article ID 6926107, 8 pages.

[45] Y. Khurshid, M. Adil Khan, Y.-M. Chu, Z. A. Khan, Hermite-Hadamard-Fejér inequalities for conformable fractional integrals via preinvex functions, J. Funct. Spaces 2019 (2019), Article ID 3146210, 9 pages.

[46] R. Kühnau, Eine Methode, die Positivität einer Funktion zu prüfen, Z. Angew. Math. Mech. 74, 2 (2012), 140-143.

[47] J. Li, J.-Y. YING, D.-X. XIE, On the analysis and application of an ion size-modified PoissonBoltzmann equation, Nonlinear Anal. Real World Appl. 47 (2019), 188-203.

[48] Y.-C. LIU, J. WU, Fixed point theorems in piecewise continuous function spaces and applications to some nonlinear problems, Math. Methods Appl. Sci. 37, 4 (2014), 508-517.

[49] W.-M. QIAN, Y.-M. CHU, Sharp bounds for a special quasi-arithmetic mean in terms of arithmetic and geometric means with two parameters, J. Inequal. Appl. 2017 (2017), Article 274, 10 pages.

[50] W.-M. QIAN, Z.-Y. HE, H.-W. ZHANG, Y.-M. CHU, Sharp bounds for Neuman means in terms of two-parameter contraharmonic and arithmetic mean, J. Inequal. Appl. 2019 (2019), Article 168, 13 pages.

[51] W.-M. QIAN, H.-Z. XU, Y.-M. CHU, Improvements of bounds for the Sándor-Yang means, J. Inequal. Appl. 2019 (2019), Article 73, 8 pages.

[52] W.-M. QIAN, X.-H. ZHANG, Y.-M. CHU, Sharp bounds for the Toader-Qi mean in terms of harmonic and geometric means, J. Math. Inequal. 11, 1 (2017), 121-127.

[53] S.-L. QIU, X.-Y. MA, Y.-M. CHU, Sharp Landen transformation inequalities for hypergeometric functions, with applications, J. Math. Anal. Appl. 474, 2 (2019), 1306-1337.

[54] S.-L. Qiu, M. K. Vamanamurthy, M. Vuorinen, Some inequalities for the growth of elliptic integrals, SIAM J. Math. Anal. 29, 5 (1998), 1224-1237.

[55] Y.-Q. Song, M. Adil Khan, S. Zaheer Ullah, Y.-M. Chu, Integral inequalities involving strongly convex functions, J. Funct. Spaces 2018 (2018), Article ID 6595921, 8 pages.

[56] Y.-X. TAN, C.-X. HuAng, B. Sun, T. WANG, Dynamics of a class of delayed reaction-diffusion systems with Neumann boundary condition, J. Math. Anal. Appl. 458, 2 (2018), 1115-1130.

[57] Z.-L. TIAn, Y. LiU, Y. Zhang, Z.-Y. LiU, M.-Y. TiAn, The general inner-outer iteration method based on regular splittings for the PageRank problem, Appl. Math. Comput. 356 (2019), 479-501.

[58] W.-S. WANG, On A-stable one-leg methods for solving nonlinear Volterra functional differential equations, Appl. Math. Comput. 314, (2017), 380-390.

[59] M.-K. WANG, Y.-M. CHU, Refinements of transformation inequalities for zero-balanced hypergeometric functions, Acta Math. Sci. 37B, 3 (2017), 607-622.

[60] M.-K. WANG, Y.-M. CHU, Landen inequalities for a class of hypergeometric functions with applications, Math. Inequal. Appl. 21, 2 (2018), 521-537.

[61] M.-K. WANG, Y.-M. CHU, Y.-P. JIANG, Ramanujan's cubic transformation inequalities for zerobalanced hypergeometric functions, Rocky Mountain J. Math. 46, 2 (2016), 679-691.

[62] M.-K. WAng, Y.-M. ChU, S.-L. QIU, Y.-P. JIANG, Convexity of the complete elliptic integrals of the first kind with respect to Hölder means, J. Math. Anal. Appl. 388, 2 (2012), 1141-1146.

[63] M.-K. Wang, Y.-M. ChU, Y.-F. QIU, S.-L. QIU, An optimal power mean inequality for the complete elliptic integrals, Appl. Math. Lett. 24, 6 (2012), 887-890.

[64] M.-K. WANG, Y.-M. CHU, W. ZHANG, Monotonicity and inequalities involving zero-balanced hypergeometric function, Math. Inequal. Appl. 22, 2 (2019), 601-617.

[65] M.-K. Wang, Y.-M. CHu, W. ZHAng, Precise estimates for the solution of Ramanujan's generalized modular equation, Ramanujan J. 49, 3 (2019), 653-668. 
[66] W.-S. WANG, Y.-Z. Chen, H. FAng, On the variable two-step IMEX BDF method for parabolic integro-differential equations with nonsmooth initial data arising in finance, SIAM J. Numer. Anal. 57, 3 (2019), 1289-1317.

[67] J.-F. WANG, X.-Y. CHEN, L.-H. HuANG, The number and stability of limit cycles for planar piecewise linear systems of node-saddle type, J. Math. Anal. Appl. 469, 1 (2018), 405-427.

[68] J.-F. WANG, C.-X. HuAng, L.-H. HuAng, Discontinuity-induced limit cycles in a general planar piecewise linear system of saddle-focus type, Nonlinear Anal. Hybrid Syst. 33 (2019), 162-178.

[69] M.-K. WANG, Y.-M. LI, Y.-M. CHU, Inequalities and infinite product formula for Ramanujan generalized modular equation function, Ramanujan J. 46, 1 (2018), 189-200.

[70] H. WANG, W.-M. QIAN, Y.-M. ChU, Optimal bounds for Gaussian arithmetic-geometric mean with applications to complete elliptic integral, J. Funct. Spaces 2016 (2016), Article ID 3698463, 6 pages.

[71] J.-L. WANG, W.-M. QIAn, Z.-Y. HE, Y.-M. ChU, On approximating the Toader mean by other bivariate means, J. Funct. Spaces 2019 (2019), Article ID 6082413, 7 pages.

[72] M.-K. WANG, S.-L. QIU, Y.-M. CHU, Infinite series formula for Hübner upper bound function with applications to Hersch-Pfluger distortion function, Math. Inequal. Appl. 21, 3 (2018), 629-648.

[73] G.-D. WANG, X.-H. ZHANG, Y.-M. CHU, A power mean inequality involving the complete elliptic integrals, Rocky Mountain J. Math. 44, 5 (2014), 1661-1667.

[74] M.-K. WANG, W. Zhang, Y.-M. ChU, Monotonicity, convexity and inequalities involving the generalized elliptic integrals, Acta Math. Sci. 39B, 5 (2019), 1440-1450.

[75] S.-H. WU, Y.-M. CHU, Schur m-power convexity of generalized geometric Bonferroni mean involving three parameters, J. Inequal. Appl. 2019 (2019), Article 57, 11 pages.

[76] J. WU, Y.-C. LiU, Note for the tripled and quadruple fixed points of the mixed monotone mappings, Bull. Korean Math. Soc. 50, 3 (2013), 993-1005.

[77] D.-X. XIE, J. LI, A new analysis of electrostatic free energy minimization and Poisson-Boltzmann equation for protein in ionic solvent, Nonlinear Anal. Real World Appl. 21 (2015), 185-196.

[78] H.-Z. XU, Y.-M. ChU, W.-M. Qian, Sharp bounds for the Sándor-Yang means in terms of arithmetic and contra-harmonic means, J. Inequal. Appl. 2018 (2018), Article 127, 13 pages.

[79] ZH.-H. YANG, Y.-M. CHU, A monotonicity property involving the generalized elliptic integral of the first kind, Math. Inequal. Appl. 20, 3 (2017), Article 127, 729-735.

[80] ZH.-H. YANG, Y.-M. CHU, M.-K. WANG, Monotonicity criterion for the quotient of power series with applications, J. Math. Anal. Appl. 428, 1 (2015), 587-604.

[81] ZH.-H. YANG, Y.-M. CHU, W. ZHANG, High accuracy asymptotic bounds for the complete elliptic integral of the second kind, Appl. Math. Comput. 348 (2019), 552-564.

[82] X.-S. YANG, C.-X. HuAnG, Z.-C. YANG, Stochastic synchronization of reaction-diffusion neural networks under general impulsive controller with mixed delays, Abstr. Appl. Anal. 2012 (2012), Article ID 603535, 25 pages.

[83] ZH.-H. YANG, W.-M. QIAN, Y.-M. CHU, Monotonicity properties and bounds involving the complete elliptic integrals of the first kind, Math. Inequal. Appl. 21, 4 (2018), 1185-1199.

[84] ZH.-H. YANG, W.-M. QIAN, Y.-M. ChU, W. ZhANG, Monotonicity rule for the quotient of two functions and its application, J. Inequal. Appl. 2017 (2017), Article 106, 13 pages.

[85] ZH.-H. YANG, W.-M. QIAN, Y.-M. CHU, W. ZhANG, On rational bounds for the gamma function, J. Inequal. Appl. 2017 (2017), Article 210, 17 pages.

[86] ZH.-H. YAng, W.-M. QIAN, Y.-M. ChU, W. Zhang, On approximating the error function, Math. Inequal. Appl. 21, 2 (2018), 469-479.

[87] ZH.-H. YANG, W.-M. QIAN, Y.-M. ChU, W. ZHANG, On approximating the arithmetic-geometric mean and complete elliptic integral of the first kind, J. Math. Anal. Appl. 462, 2 (2018), 1714-1726.

[88] ZH.-H. YANG, Y.-Q. Song, Y.-M. CHU, Bounds for the arithmetic-geometric mean, J. Inequal. Appl. 2014 (2014), Article 192, 13 pages.

[89] ZH.-H. YANG, W. ZHANG, Y.-M. CHU, Monotonicity of the incomplete gamma function with applications, J. Inequal. Appl. 2016 (2016), Article 251, 10 pages.

[90] ZH.-H. YAng, W. Zhang, Y.-M. ChU, Sharp Gautschi inequality for parameter $0<p<1$ with applications, Math. Inequal. Appl. 20, 4 (2017), 1107-1120.

[91] S. Zaheer Ullah, M. Adil Khan, Y.-M. ChU, Majorization theorems for strongly convex functions, J. Inequal. Appl. 2019 (2019), Article 58, 13 pages. 
[92] S. Zaheer Ullah, M. Adil Khan, Z. A. Khan, Y.-M. Chu, Integral majorization type inequalities for the functions in the sense of strong convexity, J. Funct. Spaces 2019 (2019), Article ID 9487823, 11 pages.

[93] T.-H. ZHAO, Y.-M. CHU, A class of logarithmically completely monotonic functions associated with a gamma function, J. Inequal. Appl. 2010 (2010), Article ID 392431, 11 pages.

[94] T.-H. ZHAO, Y.-M. CHU, H. WANG, Logarithmically complete monotonicity properties relating to the gamma function, Abstr. Appl. Anal. 2011 (2011), Article ID 896483, 13 pages.

[95] T.-H. ZhaO, M.-K. WANG, W. Zhang, Y.-M. CHU, Quadratic transformation inequalities for Gaussian hypergeometric function, J. Inequal. Appl. 2018 (2018), Article 251, 15 pages.

[96] T.-H.ZHAO, B.-C.ZHOU, M.-K. WANG, Y.-M. CHU, On approximating the quasi-arithmetic mean, J. Inequal. Appl. 2019 (2019), Article 42, 12 pages.

[97] L. ZHANG, J.-L. LI, A new globalization technique for nonlinear conjugate gradient methods for nonconvex minimization, Appl. Math. Comput. 217, 24 (2011), 10295-10304.

[98] W.-J. ZHOU, F. WANG, A PRP-based residual method for large-scale monotone nonlinear equations, Appl. Math. Comput. 261 (2015), 1-7.

[99] K.-X. ZHU, Y.-Q. XIE, F. ZHOU, Pullback attractors for a damped semilinear wave equation with delays, Acta Math. Sin. 34, 7 (2018), 1131-1150. 